\title{
GEOGRAPHICAL ANALYSIS OF AGRARIAN STRUCTURE IN BOSNIA AND HERZEGOVINA: A CASE STUDY OF USKOPALJSKA VALLEY
}

DOI: http://dx.doi.org/10.18509/GBP.2020.36

UDC: 338.431]:631.115.1:303.62(497.6)

\author{
Haris Gekić \\ Ranko Mirić \\ Aida Bidžan-Gekić \\ Boris Avdić \\ Department of Geography, Faculty of Science, \\ University of Sarajevo, Bosnia and Herzegovina
}

\begin{abstract}
The farms in the Uskopaljska valley were practically family property and heritage. That has changed in the last three decades. For the purposes of this paper, we conducted a special survey among farmers to find out the most important characteristics of their farm. The results showed that of the total number of farms participating in the survey, about $71 \%$ were not older than 25 years. The concentration of the population has led to a fragmentation of the farms and an increase in the number of mixed households. The large mountainous parts of the Uskopaljska valley region are characterized by the abandonment and alienation of entire agricultural farms, especially after 1991.

The average size of the farm is less than 3 ha. Dwarf farms with a size up to 1 ha and a share of $48 \%$ dominate, which is $11 \%$ more than in 1981. Field surveys as well as cadastral map analysis indicate that the land parcels in the valley are usually 15 to 35 ares in size. We have also evaluated the parceling of agricultural land in the Uskopaljska valley by cadastral municipalities in order to draw the best possible conclusions about the agrarian structure.
\end{abstract}

Keywords: agricultural geography, farm size, cadastral analysis, farm fragmentation

\section{INTRODUCTION}

Agrarian structure implies the forms of land ownership and control, the size of the farm, the size and shape of the parcels and their spatial structure [1]. For the modern and optimal organization of agricultural production in the Uskopaljska valley, the ownership structure and size of farms and parcels are of particular importance.

The farm in the Uskopaljska valley is practically family property and heritage. The rhythm of the household also determines the rhythm of family life. Bergmann analyzes the individual characteristics of family farms and determines them as follows: the farm is not sold or purchased, but inherited; the institute of inheritance stems from the need to maintain the farm; the farmers do not operate completely economically, but their management is often irrational; the potential of the agricultural workforce is very flexible and linked to family structure, depending on the gender and age of the members [2].

Changes in the ownership structure indirectly influence the change in the economic strength of the farm, as well as the tendencies in strengthening or weakening certain groups of farms. Both ownership structure and property relations depend first and foremost on the degree of development of productive forces. The agrarian structure is a term that denotes the ownership structure in agriculture, that is, who owns agricultural 
land and how it is distributed among land users, usually according to the size of the property [3].

The ownership structure could be defined as a systematic representation of the distribution of the land fund through individual categories of estates determined by size. There are, however, authors who define the agrarian structure in a narrower and broader sense. In the narrow sense, this agrarian-geographical term denotes the structure of farms by size. The agrarian structure in the broad sense consists of the structure and content of the overall relations in agriculture. The broader framework of this system is the forms and development of the general organization of agriculture and its integration into the national economy [4].

\section{MATERIALS AND METHODS}

The aim of this paper is to examine main changes in agrarian structure of Uskopaljska valley, Bosnia and Herzegovina. We explore: ownership structure, farm size and characteristics of parcels. Basic socio-geographical statistic material was obtained through direct and indirect research methods such as surveys and various documentation. The thematic maps were made in order to visually present the geographical distribution of the analyzed parameters using the GIS tool. We conducted a special survey for farms during 2018 [5] that was designed in accordance with the requirements of the paper. The survey consisted of 25 questions answered by leading people at farms (from size of farm to their economic situation). It covered 310 farms in the area of the Uskopaljska valley. The basic literature for land use assessment was the cadastral data and plans.

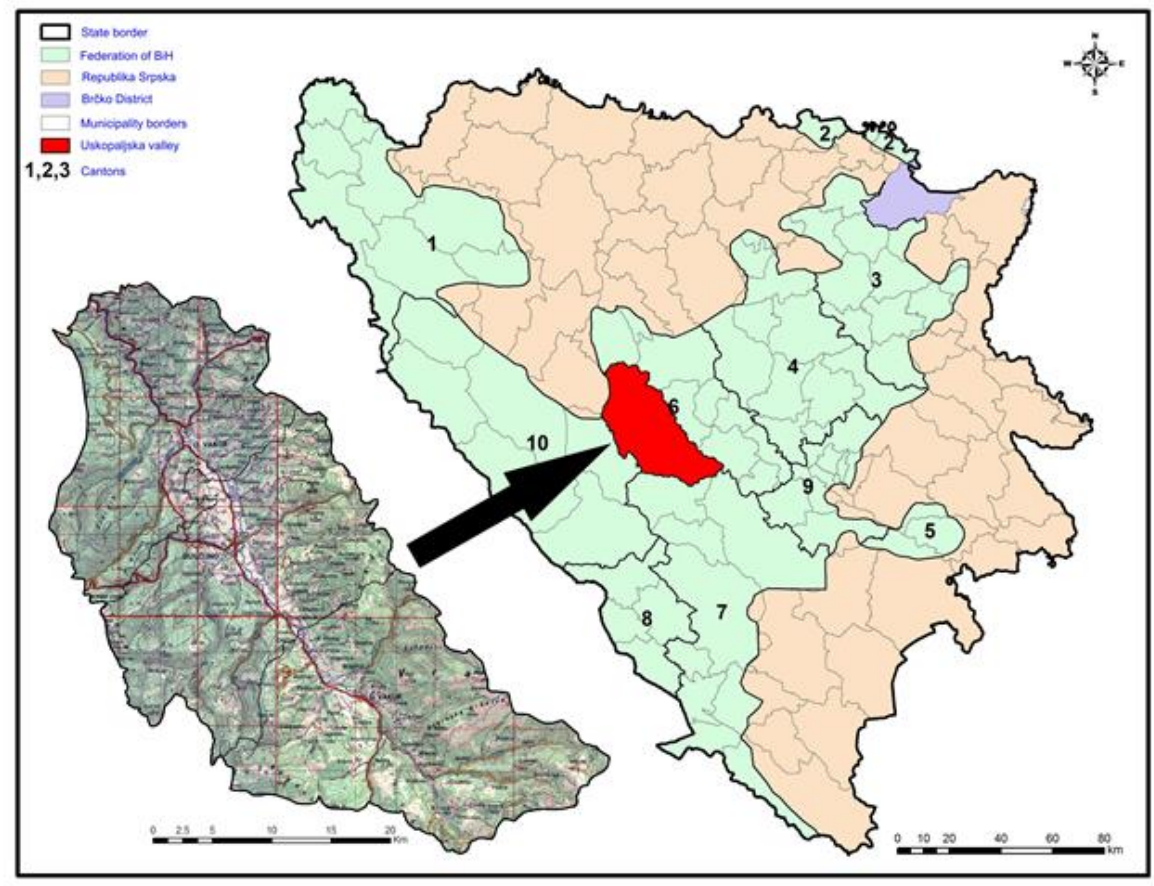

Figure 1. Location of Uskopaljska Valley region in Bosnia and Herzegovina

Geographical position of the Uskopaljska valley has the following characteristics: it is situated in the Northern Hemisphere, in the field with geographic coordinates $43^{\circ} 51^{\prime}$ and $44^{\circ} 15^{\prime}$ North latitude, and between $17^{\circ} 16^{\prime}$ and $17^{\circ} 51^{\prime}$ East longitude. The main hydrographic skeleton of the Uskopaljska Valley area is presented with the Vrbas River 
and its tributaries. The entire area of the region can be divided into three characteristic hypsometric zones important for agricultural production: the hilly zone with the domination of alluvial plains 420-600 m above sea level, covers approximately $7.35 \%$ of the observed area; the hilly zone with the dominance of depression hills covers altitudes from 601 to $750 \mathrm{~m}$ above sea level (15.6\% of the total observed area); the mountain zone extends at altitudes above $750 \mathrm{~m}$ and occupies about $77 \%$ of the observed area [6]. Political-geographically, the Uskopaljska valley is situated in the state of Bosnia and Herzegovina, the entity of the Federation of Bosnia and Herzegovina, and within it, in the Central Bosnian Canton (Figure 1). Regional-geographically, it belongs to the MountainValley macroregion, and the Upper Vrbas-Pliva mesoregion of Bosnia and Herzegovina. In Uskopaljska valley there are three administrative municipalities: Bugojno (31.470 population), Donji Vakuf (14.739 population) and Gornji Vakuf-Uskoplje (22.304 population). By roads, Uskopaljska Valley is almost equally away from the cities of Banja Luka, Sarajevo, Mostar, and Split (around $140 \mathrm{~km}$ ). The total length of border of Uskopaljska valley towards the neighbouring municipalities is $259 \mathrm{~km}$ and in those borders the Uskopaljska valley around 1.087,2 square kilometers in area. According to the Census 2013 in Uskopaljska Valley lives 68.513 people [7]. The total area of built land in urban cadastral municipalities today is 794 ha, which is only $0.7 \%$ of the area of the Uskopaljska valley. In total there is 50 cadastral municipalities [8].

\section{RESULTS AND DISCUSSION}

Within the survey on farms, we examined the maturity of the farm, that is, the beginning of production on the farm. Of the total surveyed, $71 \%$ of farms are under 20 years of age. The number of farms in the Uskopaljska valley that are over 70 years old occupies only $6.2 \%$. When analyzing the maturity of farms at the municipal level, significant differences are noted. In Bugojno municipality, $65.3 \%$ of farms are under 25 years of age, and in Donji Vakuf municipality, this proportion is $100 \%$. The reasons for this are very complex. Prior to 1991, the agricultural development in Bugojno municipality was very low compared to industrial development, and a large part of then agricultural land is completely empty today. After 1995 and the complete collapse of industry, the population increasingly turned to agricultural production. In the Donji Vakuf municipality, the reasons are of a completely different nature. From 1992-1995, the area of Donji Vakuf municipality, except for the old town of Prusac, was in the hands of the Republika Srpska army. In 1995, with the liberation of Donji Vakuf, the establishment of a completely new production began. The oldest farms are very prominent in the mountainous areas of the Uskopaljska valley (Figure 2).

Regarding the ownership of the farm in the Uskopaljska valley, four responses from the farm survey were analyzed: private-family, private, private-lease and social-lease. Of the total number of farms in the Uskopaljska valley, only $1.0 \%$ are socially owned and leased. Of the private farms, $64.2 \%$ are family-owned, inherited for generations, while $22.3 \%$ are private farms on lease from other persons. At the municipal level, the situation is very similar. The largest number of family farms is in the territory of Bugojno municipality, namely $67.8 \%$, and the largest number of private farms is in the territory of Gornji Vakuf municipality, namely 33.3\%. The municipality of Donji Vakuf has the largest number of private leased land of $20.0 \%$ compared to other municipalities.

The emergence of family farms in the Uskopaljska valley is linked to the process of abolishing feudalism in the late 19th and early 20th century, and shortly thereafter, the collapse of single-house cooperatives and the individualisation of agriculture. There are 
two distinct periods in this historical development. The first covers around 50 years from the inception of the family farms to the end of World War II. In the following period, accelerated industrialization, followed by rapid deagrarization and other modernization processes, has lead to a radical transformation of the entire agrarian area as an integral part of modernization processes and the transition from agrarian to an industrial-urban type of society in Bosnia and Herzegovina as a whole. As agriculture was dominated by the private sector, it meant amplifying the "economic impact of the state on farmers". Until 1992, the aforementioned ownership relations prevailed in the area of the Uskopaljska valley. Moving to a market-based economy enabled the full functioning of private farms.

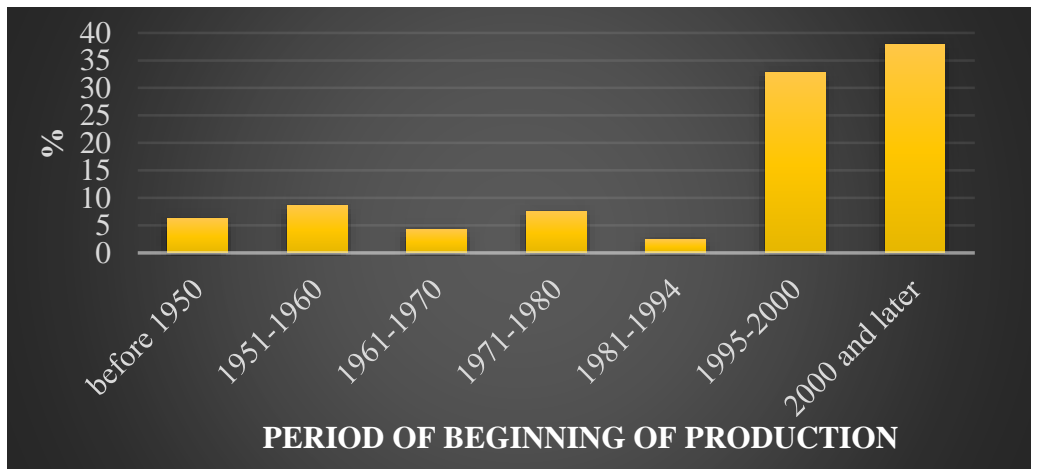

Figure 2. Maturity of farms by time periods (in \%), 2018

In the ownership structure of agricultural land in the Uskopaljska valley and within municipalities, in 2013, the participation of the private sector is dominant. Privately owned is an $82.8 \%$ of the total agricultural area of the Uskopaljska valley. In terms of municipalities, private sector participation in total agricultural areas ranges from $68.1 \%$ in Gornji Vakuf to $93.4 \%$ in Donji Vakuf. Of the total land area under arable land in the Uskopaljska valley, privately-owned is $96.7 \%$ or 14,631 ha. Private sector participation in the total arable land in Bugojno municipality is $95.2 \%$ or 6,184 ha, in Donji Vakuf municipality $99,2 \%$ or 5,371 ha and in Gornji Vakuf municipality $95,4 \%$ or 3,077 ha. The share of the private sector in total land under orchards ranges from $91.8 \%$ in Gornji Vakuf municipality, then in Bugojno municipality $90.6 \%$ and $89.9 \%$ in Donji Vakuf municipality.

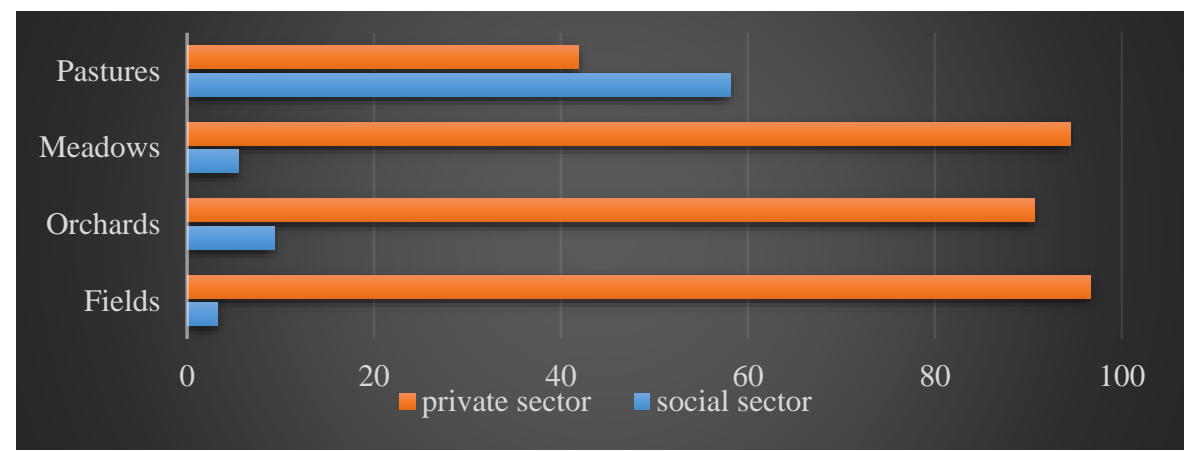

Figure 3. Ownership structure of arable land in Uskopaljska Valley, 2018

Of the total 19,823 ha of land under permanently green areas, meadows and pastures, $71.7 \%$ belong to the private sector in the Uskopaljska valley. The share of municipalities in total agricultural land under meadows ranges from $94.7 \%$ in Bugojno municipality to 
95.3\% in Donji Vakuf municipality. By contrast, 4,995 ha of land under pastures are privately owned or $58.1 \%$ of the total lands under the grass cover in the Uskopaljska valley. Most pastures in the private sector are in the Gornji Vakuf municipality 3,713 ha or $73.9 \%$ (Figure 3 ).

In 2013, the social sector owned $17.2 \%$ of the agricultural land fund of the Uskopaljska valley, which is almost 2 times higher than in the Central Bosnia Canton, where it is about $9 \%$ in the social sector. The causes of the relatively lower share of the social sector in the agricultural land fund should be sought in the past.

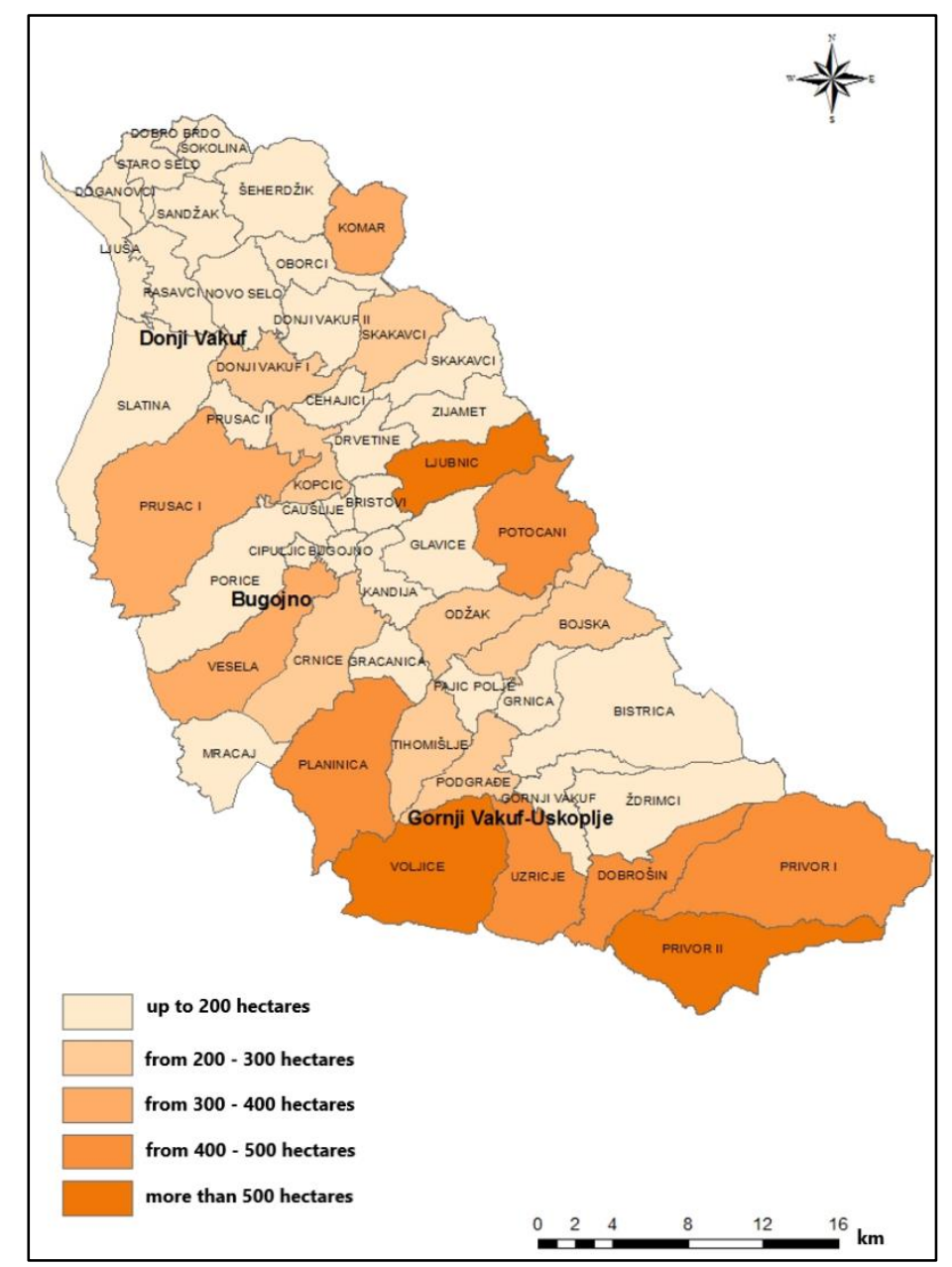

Figure 4. Meadows in private sector by cadastral municipalities, 2018

In 2013, the largest privately-owned arable land in the cadastral municipalities of Šeherdžik was 577.6 ha, Poriče 544.9 ha, Drvetine 529.5 ha, Kandija 515.2 ha, Prusac I 514.2 ha and Zijamet 510.9 ha. Most of the arable land in 2013 in the social sector was located in the alluvial plain of the Vrbas and along the lower streams of Oborački creek, Odzački creek and Veseočica river. Privately owned orchard land covers 1,191 ha. They are mainly related to the interlinear slopes and the basin rim with fewer slopes. The largest areas under privately owned orchards are in the cadastral municipalities: Prusac I about 61 ha, Kopčić about 46 ha, Poriče about 56 ha, Glavice 61 ha, Kandija 51 ha, Odžak 51.5 ha, Podgrađe 57 ha and Ždrimci $46 \mathrm{Ha}$. Lands under orchards in the social sector cover an area of 122 ha and are spatially linked to the alluvial plain of Vrbas and the lower eastern rim of the Uskopaljska valley. Over $65 \%$ or 80 ha of land under orchards in the 
social sector are located in the previously mentioned urban cadastral municipalities. A significant land complex of about 33 ha under orchards extends east of Vrbas in hilly Kandija.

The largest areas under meadows in the private sector are in the cadastral municipalities of Voljice 640.3 ha, Privor II 577.6 ha, Ljubnić 557.7 ha, Uzričje 492.8 ha and Planinica 487.3 ha. The largest areas under meadows in the social sector are located in cadastral municipalities Privor I 191.9 ha, Potočani 63.6 ha, Crniče 45.0 ha, Odžak 31.2 ha and Poriče 29.9 ha. The largest areas under pastures in the social sector are in the cadastral municipalities located in the southeast area of Vranica Mountain, Privor I 1,874.8 ha, Ždrimci 557 and Privor II, 322 ha. The largest areas under pastures in the private sector are in the cadastral municipalities of Skakavci 190.1 ha, Šeherdžik 170.0 ha, Voljice 162.4 ha and Donji Vakuf II 161.5 ha (Figure 4).

The greater share of agricultural land is the result of large areas under pasture in the social sector, especially in the area of the Vranica mountain range in the southeast, which mixes with forests much like in other parts of the Uskopaljska valley. Pastures are majorityowned by the social sector. For the aforementioned reasons, no significant areas in the social sector, especially of good quality agricultural land, were formed in the Uskopaljska valley. Namely, out of 6,237 ha of agricultural land in the social sector, as many as 5,670 ha, or $90 \%$ of it belongs to low-productive land under pastures and meadows.

The size of farms is one of the most important economic and social factors of agricultural activity. It depends, among other things, on what agricultural production will be like and how many market surpluses will be. Equally important is its social role, as socially disordered agricultural ownership structure is often a source of frustration for poorer classes of farmers and social unrest [9].

The size of the estate is an important factor in the rationality and profitability of agricultural production in the Uskopaljska valley. In 1960, the smallest estates in the Uskopaljska valley were from 1 to 3 ha, $43.8 \%$ of the total of 8.119. The share of medium estates, 3 - 5 ha in size, in the Uskopaljska valley was $15.8 \%$.

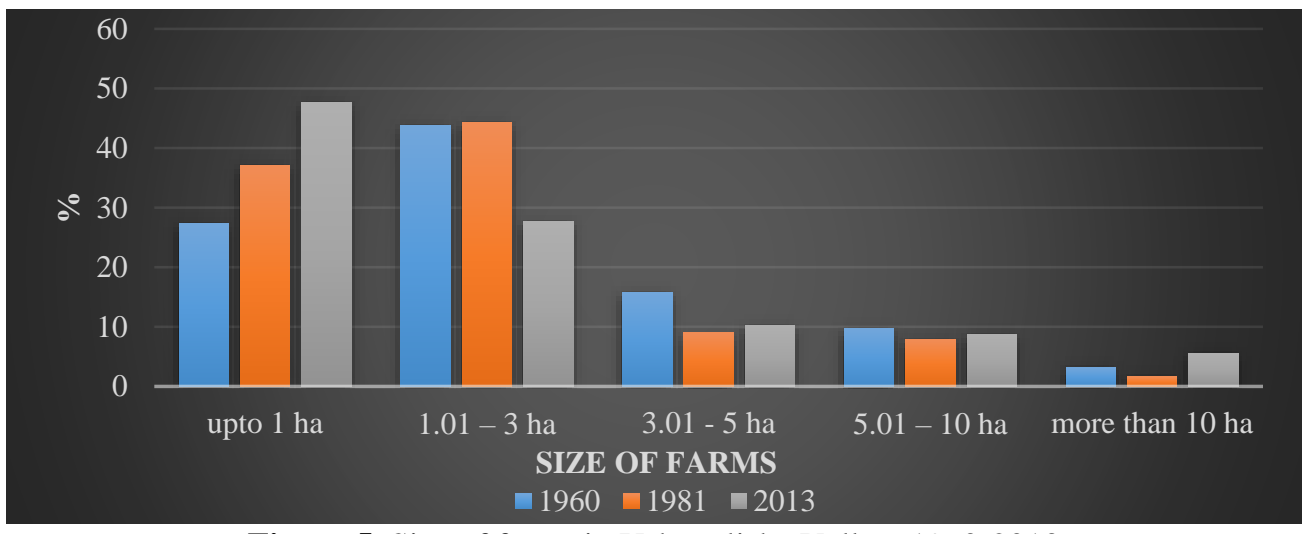

Figure 5. Size of farms in Uskopaljska Valley, 1960-2013

In 1960, there were 8,119 private farms in the Uskopaljska valley, which had 24,312 ha of agricultural land available. Therefore, the average size of private farms was about 3 ha of agricultural land (Figure 5).

However, if only arable land, about 14,000 ha, is taken into account, then the average size of private farms is significantly reduced to just 1.7 ha. Viewed by cadastral municipalities, the average size of private farms in the Uskopaljska valley ranged from 1.3 ha in Bugojno to over 5 ha in the cadastral municipalities of Skakavci and Privor I. 
In 1981, there are noticeable changes in the structure of estates by size in the Uskopaljska valley. The difference in farms between small and dwarf estates was reduced by $9.2 \%$. The largest share is for small estates $(44.3 \%)$.

The share of medium-sized land, 3-5 ha, was reduced in the Uskopaljska valley by $6.8 \%$ to $9.0 \%$. The share of large estates in the Uskopaljska valley was reduced by $1.5 \%$ to $1.7 \%$. The biggest share of large estates was in the municipality of Gornji Vakuf $2.2 \%$, then in the municipality Donji Vakuf $1.6 \%$ and in the municipality Bugojno $1.5 \%$.

Compared to 1960, in 1981, the average size of farms in the Uskopaljska valley decreased slightly and amounted to 2.6 ha of agricultural land. If only arable land is analyzed, the average size of the farm is $1.8 \mathrm{ha}$. At the same time, in the period 1961-1981, the number of private farms increased by 2,272 or by around $28 \%$. As a result of the inheritance division, the number of medium-sized, 3-5 ha, large, 5-10 ha, and the largest, over 10 ha, private farms was reduced from 2,338 in 1960 to 1,923 in 1981, and the number of dwarf estates increased to 1 ha, and small estates, 1-3 ha, private farms from 5,812 to 8,468.

The average size of private farms in 1981 within the Uskopaljska valley was very different. The largest farms were in the mountainous cadastral municipalities in the north Sandžak 5.5 ha, Sokolina 6.1 ha, in the east in the area of mountainous Zijamet 5.1 ha, and in the southeast in the area of Bistrica 5.3 ha and Privor I 7.1 ha, the area of the Vranica mountain range, Mračaj 6.3 ha in the southwest and Planinica 5.7 ha, as a result of the large share of meadows and pastures in the agricultural land of these farms. Medium-sized farms show domination of an average of 1.01 to 3 ha along the most favorable part of the Uskopaljska valley, the alluvial plain of Vrbas, river terraces and basin hill.

Almost all cadastral municipalities, which extend in mountainous areas above $750 \mathrm{~m}$, have a high share of meadows in the total agricultural land. The mountain rim is characterized by an absolute decrease in the total number of farms and an increase in the average size of estates. The total number of farms in this area was reduced by $15 \%$ in the period of 1961-1991, while on the other hand, the average size of estates increased from 3.2 ha to over 3.6 ha. For example, in the cadastral municipality of Sokolina, the total number of farms has been reduced from 60 to 36, in Doganovci from 46 to 34, in Mračaj from 42 to 17, etc. The average size of estates in some cadastral municipalities of the northeast and southeast, as well as southwest, exceeds 5 ha.

The increase in the total number of private farms in the period of 1960-1991 is present in all cadastral municipalities of the alluvial plain of Vrbas, on river terraces, as well as on the slopes of lake sediments. The rural settlements of these cadastral municipalities are very well connected to the urban centers. These are also settlements with a high proportion of mixed households in the total number of households engaged in agriculture. A very important feature of the development of the total number of farms in the Uskopaljska valley in the period of 1960-1991 is the increase in the number of private farms from 8,119 to 11,239 , or by as much as $38.4 \%$. The increase in the total number of farms is a consequence of the very rapid increase in farms up to 3 ha in size.

The concentration of the population has led to the fragmentation of property and an increase in the number of mixed households in the Vrbas valley and its significant tributaries. The large mountainous parts of the Uskopaljska valley are characterized by the abandonment and alienation of entire farms, especially after 1991. Arable lands that are more remote and of poor quality, with a higher incline of slopes, are completely abandoned. After 1991, due to the absence of the Agricultural Census and a 
comprehensive register of farms in Bosnia and Herzegovina, there is no accurate data on the number or size of all estates, which tried to make up for by the survey.

In 2013, the estates of the Uskopaljska valley experienced even greater fragmentation than in previous periods. According to the Survey on Farms, the Uskopaljska valley is dominated by dwarf estates up to 1 ha in size. Their share is as high as $47.7 \%$, which is an increase of $10.6 \%$ compared to 1981 . In the second place by a share in the area are small estates with size from 1 to 3 ha whose share in the Uskopaljska valley is $27.7 \%$. Together, estates with a size of less than 3 ha make up for $75.4 \%$ of estates.

According to the Survey on Farms (2018), the average size of land in the Uskopaljska valley is 2.8 ha. The largest in the municipality of Gornji Vakuf is 3.3 ha and the smallest in the municipality of Donji Vakuf is 1.8 ha. The largest number of farms is in the size group up to 1 ha, as high as $47.7 \%$, while only $5.6 \%$ has a farm of over 10 ha.

It is also important to highlight a significant share of 1-3 ha farms of $27.7 \%$, however, their characteristic is the unfavorable structure of utilization of agricultural land, and most of them are meadows and pastures that are poorly used. The largest estates appear in areas outside the alluvial plain Vrbas and near river flows.

Most of the bottom and perimeter areas of the Uskopaljska valley, along the Vrbas river, are characterized by the participation of dwarf and small farms in the total number of farms, which exceeds $80 \%$. It is a natural-geographical entity that has the most favorable agrarian-geographical potential for intensive agricultural production. The reduction in the size of the land, along with other factors, has led to more intensive use of the available arable land. In the current distribution of agricultural production, these are areas where intensive vegetable production is represented because it enables high yields and profit even on small arable land.

The aforementioned analysis clearly indicates that one of the most important problems in the modern development of agriculture in the Uskopaljska valley is the fragmented possession, which prevents greater production of cereals in particular. That is why the agricultural production of the Uskopaljska valley should be directed as much as possible towards the cultivation of vegetables and fruits, especially berries.

For the sake of comparison, the agrarian structure, for example, of Polish agriculture, is in a better position than that of Bosnia and Herzegovina in terms of the size of the estate. However, it is more fragmented than Germany. Very small farms up to 5 ha, which make up 55.2\% of the total number of farms in Poland, do not have the conditions to use labor effectively and provide adequate income to support families and to develop farms. Moreover, such farm companies are unable to compete in the European market. Polish agriculture is dominant with the family ownership model similar to that in the Uskopaljska valley [10].

The advantage of small farm was usually referred to as production that is labor-intensive - vegetable growing, floriculture, viticulture, olive growing, or agriculture in mountainous areas where the use of machinery is restricted. In addition, small farms carry out more careful work, which is particularly important in livestock farming; all family members, including those who could not be employed outside the farm, are engaged; small estates are more resilient to economic disruption; they are more flexible and adaptable [11].

The benefits of large farms in the Uskopaljska valley can be summed up in several points: higher productivity of labor and production means; more rational and full use of material resources and labor; higher quality of certain technical procedures used in breeding plants and animals; greater ability to apply the results of scientific and technical progress; as a rule, higher production per unit of capacity; lower unit cost of production; greater degree 
of specialization and division of labor; more favorable position on the market for agricultural products and inputs as well as on the financial market; more profitable production.

The advantages of large farms are also the disadvantages of small farms. The fragmentation of the property can be overcome by indirect land division. Also, one of the possibilities is to arrange land for joint cultivation, ie to organize joint production on the estates of farmers. This represents the gradual deletion of boundaries and the creation of larger land complexes. Objective processes that are present on private farms, fragmentation and rapid development of mechanization require that the land complex be enlarged. These processes, which are gradually evolving in the Uskopaljska valley, are already widely present in the countries of the European Union [12].

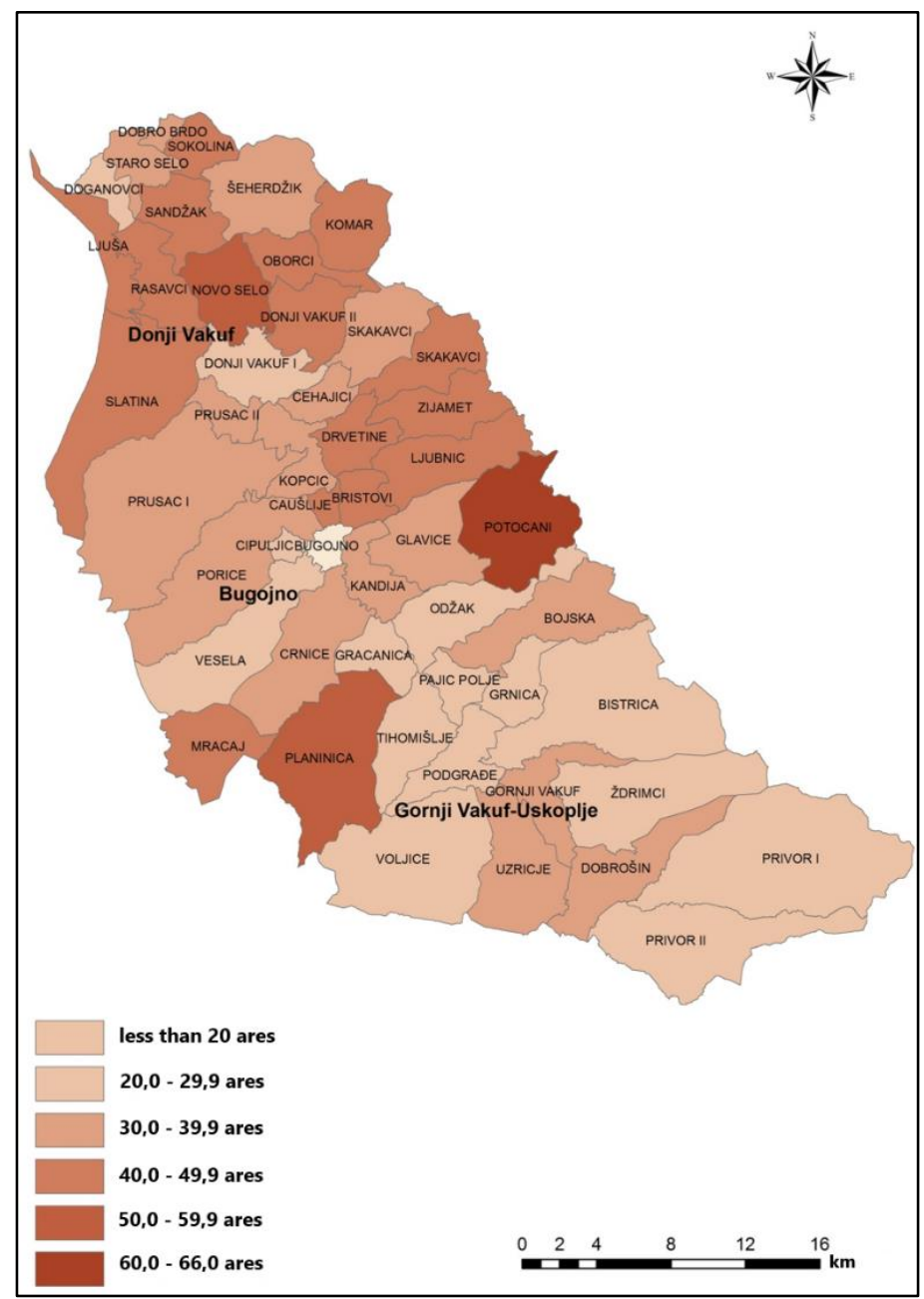

Figure 6. Size of parcels by cadastral municipalities, 2018

A parcel is the smallest spatial unit in the organization of agricultural production. From its shape and size, pedological features and slopes, depend on the costs of production and the level of the yield of agricultural crops. In addition, a very important factor in the rationality of crop production is the distance of the parcel from the farm. Parcelization is the subdivision of land into smaller parts, parcels. In this context, the fact is that the two processes are happening: splitting larger estates, family farms or larger parcels into smaller parcels; consolidation, the concentration of small possessions or parcels into larger ones. 
Land parceling is done in a number of ways: by dividing land through inheritance, by dividing land by buying or selling land, by an agrarian reform or by the allocation of undistributed land, by expropriating farmers' land for other purposes.

The size of the parcels of private farms in the Uskopaljska valley is determined by the size of the property, the area of arable land, the structure of crop production and the hereditary division in the past. Also, smallholder farms in the river valleys under conditions of diversified crop production are forced to cultivate different crops such as corn and vegetables on the same parcel, which reduces the rational use of machinery. In smaller parcels, the yield is lower because considerable areas fall on the borders where the quality of cultivation is much worse and the conditions for successful crop cultivation are less favorable and the yield per unit area is lower.

In addition, the boundaries of parcels in the alluvial plain of the rivers and on the river terraces of the Uskopaljska valley are characterized by individual trees such as ash, poplar and willow, and various weed plants. Along the shores of the Vrbas and its tributaries, varied hydrophilic vegetation such as willow and alder extend in the belts. In the midst of the parcels of the mountainous rim of the valley beside trees and weeds, shrubs are increasingly occurring due to lack of workforce. Vegetation reduces the quality of arable land and the length of solar irradiance, and therefore the quality of fruits and yields per unit area.

Privately owned agricultural land of the Uskopaljska valley, 30,032 ha, has been divided into about 90,000 parcels so that the average parcel size in the Uskopaljska valley is 33 ares. Land surveys, as well as cadastral map analysis, indicate that the parcels in the basin are usually 15 to 35 ares in size. With the distance from the basin plane to the basin rim, the size of the parcels increases. The smallest parcel of agricultural land is in the central part of the Uskopaljska valley in the cadastral municipality of Bugojno, and amounts to 14 ares (Figure 6).

It is particularly interesting to note that the parcels south of Bugojno, used for intensive agricultural production, are only slightly larger, averaging about 10 ares. The largest size of the parcels is in the cadastral municipalities of the mountainous outskirts, which have a low population density and whose agricultural land is of lower grade, in Potočani 65 ares or 0.65 ha, Planinica and Novo Selo 50 ares or 0.5 ha. The average size of the parcel under arable land in the Uskopaljska valley is 33 ares or 0.33 ha and the spatial distribution by cadastral municipalities corresponds to the layout of agricultural parcels. Unlike the previous parcel under the orchards, they are far smaller, the average for the Uskopaljska valley is only 10 ares or 0.1 ha. The largest parcels under the orchards are located in the cadastral municipalities: Bugojno 0.17 ha, Prusac II 0.16 ha, Bristovi 0.12 ha, and the least in the most forested areas of the mountainous part of the Uskopaljska valley: Mračaj 0.03 ha, Privor I 0.04 ha, Privor II 0.05 ha and Voljice 0.06 ha. The average size of meadow parcels is almost half an acre, 0.49 , and is the largest in mountainous areas much like pasture parcels. It can be concluded that the average sizes of parcels under meadows and pastures are favorable for the development of agricultural production, while parcels under orchards are very small. The degree of parceling is determined on the basis of the number of parcels of arable land belonging to one property, according to the Polish Instruction for the Study of Land Use in the World, accepted by the International Geographical Union: I degree of parceling - up to 5 parcels per farm; II degree of parceling - from 5 to 10 parcels per farm; III degree of parceling - more than 10 parcels per farm [13] (Figure 7). 
The first degree of parceling is also characteristic of urban areas and areas of concentration of population, mainly along the Vrbas river and along the left tributary of the Prusac River. The degree of parceling increases in the area where parceling and preparation can be accessed separately in the area outside urban areas and at higher altitudes of the Uskopaljska valley.

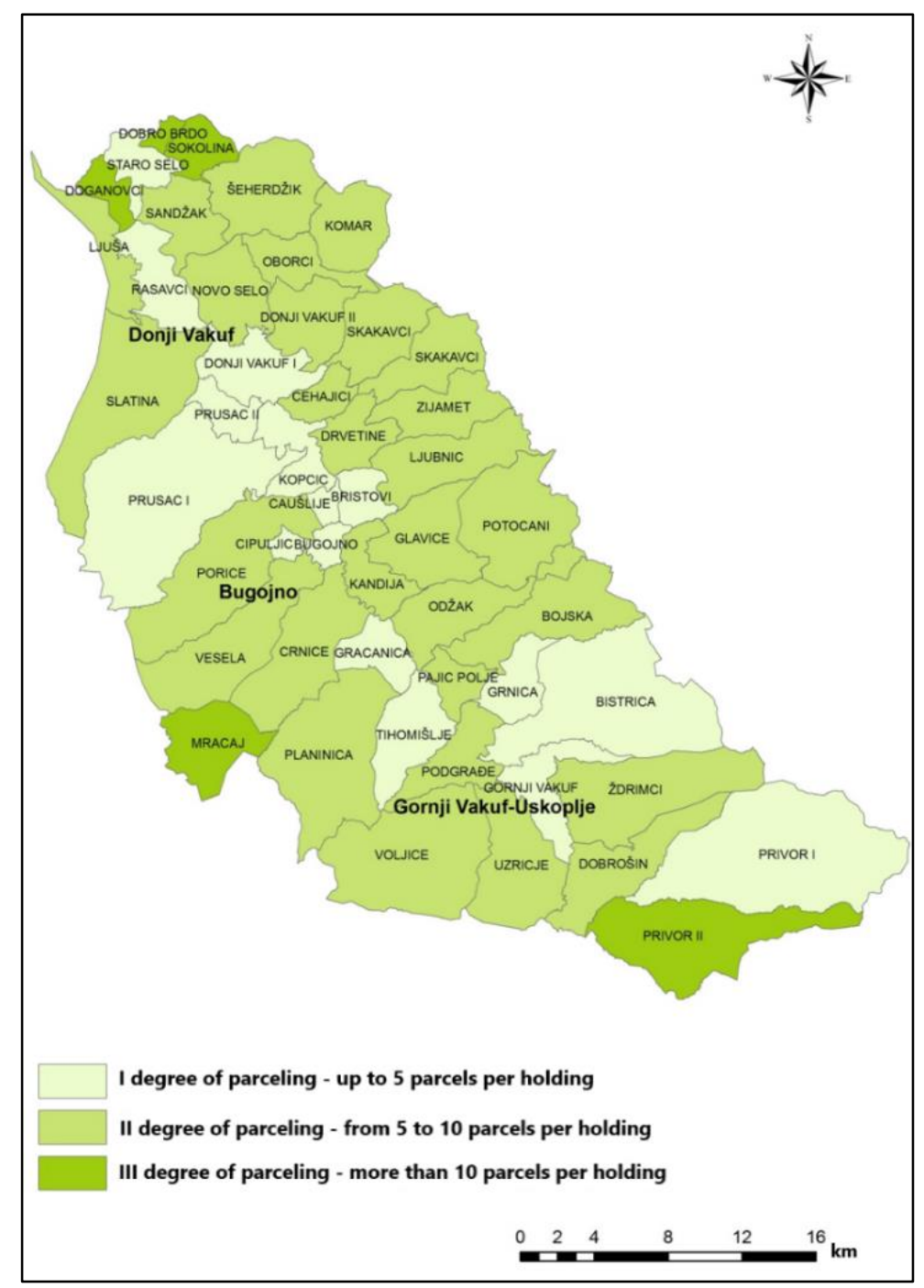

Figure 7. Degree of parceling by cadastral municipalities, 2018

Very important parameters for evaluating the optimal organization of crop production are the shape and length of the parcel. The shape of the parcel affects the degree of use of the means of mechanization and the cost of performing the mechanization processes. In terms of rational use of agricultural machinery, parcels of rectangular shape are most suitable. Parcels of the Uskopaljska valley are characterized by a regular geometric, mostly rectangular shapes. The mosaic layout of the parcels prevails, as they are most often differently oriented according to the primary division. Parcels of regular shape are also found along with the middle and lower parts of the valleys of Poričnica, Veseočica, Oborački creek and Drvetinska river. Moving further towards the perimeter of the basin at higher elevations, the parcels gradually lose their rectangular shape and become more square and irregular in shape. For example, the parcels of the western rim of the basin, the areas of the cadastral municipality of Crniče, are of different shape, length and size of 
10 ares, up to 100 ares. The effect and costs of mechanization processes depend on the length of the parcel. With the increase in the length of the parcel, when working with the same means of work, the number of revolutions of the aggregate and the time losses during the rotation decrease, and the basic time and thus the effect increase. For example, on a parcel, $400 \mathrm{~m}$ long compared to a $50 \mathrm{~m}$ parcel, the effects are $61.3 \%$ higher in basic cultivation, $55.4-63.6 \%$ in crop care, $56 \%$ in wheat harvest, and even $226 \%$ in maize harvest [14].

The length, shape and size of the parcels of the Uskopaljska valley are the results of agrarian-property relations in the past and an inheritance division in the post-World War II period. Agricultural parcels, as well as estates, were created in different ways. During the reign of the Ottoman Empire, longitudinal subdivision into large parcels spread over the entire length of the cadastral municipality, thus encompassing land of different production values, prevailed. During the Austro-Hungarian rule, there was a fragmentation of parcels in different directions, but so that each farm received land with similar production potential. The disintegration of family cooperatives between the two world wars and the inheritance division continued the tendency to subdivide the parcels and divide them by length.

That is why the parcels of the basin plane have a small width, while their length sometimes exceeds $250 \mathrm{~m}$. Due to the small width and slope, the cultivation of these parcels with modern agricultural machinery is possible perpendicular to the isohypses. This method of land cultivation increases the intensity of erosive processes. Parcels that are farther away from farms and have scarce production values, as well as parcels with a higher inclination of slopes, are now almost abandoned and gradually overgrown with degraded grass and forest vegetation.

The agricultural land of the private farms of the Uskopaljska valley, depending on the size of the property, is divided into a large number of parcels, 3-10 parcels, with different sizes and distances from the household. With the increase of the distance of the parcel from the yard of the farm, the transportation costs increase. In addition, the greater distance of the parcel makes it difficult to protect and monitor the negative effects of the vegetative stages of agricultural crop development. The distance of the parcel from the farm in the basin and in the lower streams of the larger tributaries of the Vrbas is determined by the position within the cadastral municipality, as well as by the size of that area. For example, the cadastral municipality Pajić Polje represents one of the largest agricultural areas of the Uskopaljska valley and has about 190 ha of arable land, while the distance of the parcels does not exceed $2 \mathrm{~km}$.

\section{CONCLUSION}

A detailed analysis of the size and structure of the estates and parcels of the Uskopaljska valley inevitably indicates its disadvantage. The more favorable agrarian structure is characterized only by farms that have larger land estates and parcels of the larger areas. The area of socially owned arable land ranges from 5 to 20 ha and the average parcel size is about 1 ha.

In the private sector, estates of up to 3 ha are predominant, divided into parcels of different lengths, shapes and sizes. The existing agrarian structure of the Uskopaljska valley reduces the rationality of land cultivation and the profitability of agricultural production. That is why the grouping of agricultural land and estates, and the creation of such land complexes on which rational application of modern agricultural technology and modern labor organization will be possible, is one of the significant measures of land policy. 
One of the complex questions that will be raised before the agriculture of the Uskopaljska valley and without which there are no realistic assumptions for its accelerated development, is solving the problem of the existing very unfavorable agrarian structure. It is reflected in a large number of small family farms, which are incapable of independent economic life, for their own reproduction. The productivity of working on such farms is very low and the generated income is also low. Of course, the level of marketability of these farms is low. Market and production for the market breaks the traditional closure of the rural economy and opens the process of differentiation in rural areas, which is stronger as the agricultural market is more developed.

The agricultural structure is undoubtedly unfavorable, especially when compared to developed European countries. This is a problem for most countries in transition. The only advantage over other territories and countries in transition is that the ownership of land on a large scale has been retained in the area of the Uskopaljska valley.

\section{REFERENCES}

[1] Jaćimović, B. Uticaj depopulacije stanovništva na promjene agrarne strukture u Južnomoravskom regionu, Zbornik radova Geografskog instituta 26, Serbia, 1989.

[2] Bergmann, T. Socioeconomic Situation and Perspectives of the Individual Peasent, Sociologia Ruralis 30 (1), Netherlands, pp. 48-61, 1990.

[3] Ekonomski leksikon. Leksikografski zavod "Miroslav Krleža", Masmedia, Croatia,1995.

[4] Budin, T. Agrarna struktura kao činitelj razvitka Hrvatske, Sociologija sela, 1/2, Institut za društvena istraživanja, Croatia, pp. 45-52, 1992.

[5] Farm survey in Uskopaljska valley, Bugojno, Donji Vakuf, Gornji Vakuf-Uskoplje, Bosnia and Herzegovina, 2018.

[6] Gekić, H., Bidžan-Gekić, A. Geographical analysis of the impact of the relief on the development of agriculture in Bosnia and Herzegovina: The case study of Uskopaljska Valley. RJOAS, 8, Russia, pp. 85-98, 2016.

[7] Gekić H., Bidžan A. Influence of Water Resources on Agriculture in Uskopaljska Valley. Journal of Global Resources, 2015, 1, 1, India, pp. 23-38, 2015.

[8] Archives of Municipal Cadastral Offices. Bugojno, Donji Vakuf, Gornji Vakuf-Uskoplje, Bosnia and Herzegovina, 2018.

[9] Vrišer, I. Velikost kmetijskih gospodarstev v Sloveniji, Geografski vestnik 77-1, Zveza geografskih društev Slovenije, Slovenia, pp. 9-25, 2005.

[10] Jezierska-Thole, A., Janzen, J., Rudnicki, R. Agrarian-Economic Structure of Farms in Poland and East Germany: Selected Elements of Comparative Analysis, Quaestiones Geographicae 33 (2), Poland, pp. 87-101, 2014.

[11] Cahill, C. Adjustment Policies in Europe, OECD, Directorate for Food, Agriculture and Fisheries, France, 2004.

[12] Vujatović-Zakić, Z., Tomić, R. Ekonomika poljoprivrede, Megatrend, Serbia, 1998.

[13] Stepić, M., Jaćimović, B. Osnovi agrarne geografije, Jantar grupa, Serbia, 2006.

[14] Otašević, S., Gostović, M., Rajkov, V. Parcela kao elemenat komasacije, Poljoprivredni fakultet, Serbia, 1976. 